\title{
Społeczność japońska w Stanach Zjednoczonych w latach 1930-1941. Zarys problemu
}

Stany Zjednoczone drugiej połowy XIX wieku były miejscem, w którym miliony imigrantów chciały rozpocząć nowe, lepsze życie. Nie wszyscy byli jednak mile widziani. W kraju, w którym 90\% mieszkańców było imigrantami z Europy lub ich potomkami, nie było miejsca dla imigrantów z Azji. Jako pierwsi przekonali się o tym Chińczycy. Ustawa z 1882 roku zakazywała im imigracji do USA na 10 lat $^{1}$. W następnych latach rasowe uprzedzenia skierowane zostały w stronę Japończyków, którzy przybywali do kraju w większej liczbie od 1885 roku. Imigrację z Japonii także próbowano ograniczyć. Służyć temu miał m.in. Gentlemen's Agreement of 1907-1908, nieformalne porozumienie pomiędzy rządami USA i Japonii. Zgodnie z nim USA miały nie nakładać oficjalnych ograniczeń na imigrację z Japonii, której rząd w zamian zobowiązał się nie wydawać paszportów obywatelom, którzy chcieli wyjechać do pracy w USA ${ }^{2}$. Porozumienie było jednym z pierwszych dyskryminacyjnych rozwiązań, które w następnych latach utrwaliły status Japończyków jako imigrantów drugiej kategorii.

Zdecydowana większość imigrantów z Japonii przybyła do Stanów Zjednoczonych przed uchwaleniem przez Kongres Immigration Act of 1924, który zakazywał przyjmowania do kraju imigrantów z Azji. Japończycy zamieszkiwali Hawaje, posiadające wówczas status terytorium oraz kontynentalną część państwa. Według przeprowadzonego w 1930 roku spisu powszechnego, państwo zamieszkiwało 279 tys. Japończyków. Większość z nich, 140 tys., zamieszkiwała Hawaje, pozostali byli skoncentrowani głównie na Zachodnim Wybrzeżu (120 tys.), a w szczególności w Kalifornii (97 tys.). Z oczywistych po-

\footnotetext{
1 Chinese Exclusion Act of 1882; na mocy ustawy z 1892 roku (Geary Act), zakaz został przedłużony na następne dziesięć lat. Kolejna ustawa z 1902 roku uczyniła go stałym. Szerzej w: R. Daniels, Asian America: Chinese and Japanese in the United States since 1850, Seattle 1988.

2 Zob. Y. Ichioka, The Issei: The World of the First Generation Japanese Immigrants 1885-1924, New York 1988, s. 71-72.
} 
wodów niewielu Japończyków zamieszkiwało inne regiony państwa ${ }^{3}$. Spis powszechny z 1940 roku wykazał spadek liczby Japończyków w kontynentalnej części USA do 127 tys. Wynikał on z wyjazdu części imigrantów, którzy przybyli jedynie na określony czas $\mathrm{w}$ celach zarobkowych i wymierania najstarszej generacji ${ }^{4}$. Na Hawajach liczba Japończyków wzrosła w ciągu dekady do 157 tys. Stany Zjednoczone zamieszkiwało zatem łącznie 285 tys. Japończyków ${ }^{\text {. }}$.

Społeczeństwo japońskie w Stanach Zjednoczonych (Nikkei) składało się z trzech generacji: Issei, Nisei i Sansei (ta ostatnia jednak, ze względu na swoją niewielką liczebność, nie miała wówczas większego znaczenia). Issei to najstarsza generacja, składająca się z imigrantów. Przybywali oni do USA przede wszystkim w celach zarobkowych, mimo licznych trudności związanych $\mathrm{z}$ asymilacją i wrogim nastawieniem części amerykańskiego społeczeństwa, często decydowali się pozostać na stałe. Pomimo długoletniej nierzadko obecności poza Japonią, wielu $\mathrm{z}$ nich bardzo mocno się $\mathrm{z}$ nią identyfikowało. Ich uczucie do kraju pochodzenia było żywe, a Issei odczuwali dumę z jego osiągnięć i znaczącej pozycji w polityce międzynarodowej. Stosunek do kraju zamieszkania był różny, często pełen rezerwy czy wprost niechęci. Przyjmowanie takiej postawy ułatwiali sami Amerykanie i władza państwowa, nie tylko ograniczając napływ imigrantów z Japonii. Issei, tak jak wszyscy imigranci z Azji, nie mogli zostać obywatelami USA. Zgodnie z ówczesnym prawem amerykańskim mógł nim zostać biały, czarnoskóry (od 1868) i Indianin (od 1924), natomiast Azjaci zaliczani byli do kategorii alien ineligible for citizenship. Konsekwencją takiego postrzegania Azjatów, było ustanowienie na mocy wspomnianej ustawy imigracyjnej, całkowitego zakazu ich imigracji do Stanów Zjednoczonych ${ }^{6}$.

Issei byli dyskryminowani także na inne sposoby. Jednym z najbardziej dotkliwych było wprowadzanie przez poszczególne stany ustaw zakazujących lub ograniczających im prawo do posiadania ziemi. Pierwszym z nich była Kalifornia, której legislatura zdecydowaną większością głosów (35 do 2 w Senacie i 72 do 3 w izbie niższej) uchwaliła w 1913 roku Alien Land Law, zakazującą

3 http://www.censusrecords.com/search?censusyear=1930\&race=japanese, [dostęp 23.01.2015].

4 W trakcie dekady liczba Japończyków najstarszego pokolenia, Issei, zmniejszyła się o ponad 23 tys. B. Hosokawa, Nisei: The Quiet Americans, New York 1969, s. 151.

5 Na kontynencie Japończycy stanowili bardzo mały odsetek mieszkańców, natomiast na Hawajach byli największą grupą etniczną. W 1930 roku stanowili 42,7\% mieszkańców terytorium, dziesięć lat później 37,9\%. E. C. Nordyke, Y. S. Matsumoto, The Japanese in Hawaii: a historical and demographic perspective, "The Hawaiian Journal of History" 1977, t. 11, s. 165, evols.library.manoa.hawaii.edu, [dostęp 24.01.2015].

6 Na temat braku prawa do naturalizacji i Immigration Act of 1924 zob. R. Daniels, The Politics of Prejudice: The Anti-Japanese Movement in California and the Struggle for Japanese Exclusion, Berkeley-Los Angeles-London 1977, s. 92-105; Y. Ichioka, op. cit., s. 210-226, 244-254. 
Azjatom kupowania ziemi i wydzierżawiania jej na dłużej niż trzy lata ${ }^{7}$. Następnie podobną ustawę wprowadziły inne stany: Arizona (1917), Waszyngton (1921), Luizjana (1921), Nowy Meksyk (1922), Idaho (1923), Montana (1923), Oregon (1923) i Kansas $(1925)^{8}$. Te działania w połączeniu z innymi czynnikami, takimi jak różnice rasowe czy bariera językowa powodowały, że Issei tak do końca nigdy nie zintegrowali się ze społeczeństwem amerykańskim, przynajmniej na kontynencie.

Odmiennie wyglądała sytuacja na Hawajach, mocno zróżnicowanych etniczne. Oprócz Japończyków mieszkali tam m.in. Hawajczycy, Amerykanie z kontynentu, Chińczycy, Filipińczycy, Portugalczycy, Koreańczycy, Portorykanie i Hiszpanie. Dominujący politycznie i ekonomicznie biali zachowywali dystans wobec pozostałych mieszkańców, co ułatwiło ich integrację 9 . Ponadto pomiędzy sporą częścią Japończyków i innymi mieszkańcami istniała ograniczona wspólnota interesów. W ogromnej większości byli oni imigrantami przybyłymi do pracy na plantacjach trzciny cukrowej, należących do największych korporacji nazywanych Wielką Piątką ${ }^{10}$. Zdarzały się więc sytuacje, gdy przeciwko warunkom pracy strajkowali równolegle robotnicy różnych narodowości, np. w 1920 roku zastrajkowali Japończycy i Filipińczycy ${ }^{11}$.

W sytuacji odmiennej od Issei znajdowały się ich dzieci, Nisei. Wskutek urodzenia w Stanach Zjednoczonych byli obywatelami tego państwa, a wychowanie i edukacja w amerykańskich szkołach likwidowały większość przeszkód w asymilacji. Japonia była dla nich krajem przodków i przez to była im bliska, Ameryka była miejscem ich narodzin. Ta sytuacja prowadziła do swoistego zawieszenia Nisei pomiędzy tymi dwoma państwami, pomiędzy tożsamością japońską a amerykańską, czyli tzw. Nisei problem (jap. Dai-Nisei mondai). Zewnętrzną oznaką

7 R. Daniels, op. cit., s. 62-63. Prawo to, choć dotyczyło wszystkich alien ineligible for citizenship, wymierzone było przede wszystkim w Japończyków.

8 W. Ng, Japanese American Internment during World War II, Westport-London 2002, s. 9.

9 Zamieszkiwanie Hawajów przez osoby wielu narodowości i dominująca rola języka angielskiego używanego przez białych doprowadziła do wytworzenia Hawaiian Pidgin, języka angielskiego pełnego zapożyczeń z kilkunastu języków używanych na Hawajach; zob. J. E. Reinecke, „Pidgin English" in Hawaii: A Local Study in the Sociology of Language, "American Journal of Sociology", t. 43, nr 5 (March 1938), tekst przedrukowany w: D. Ogawa, Kodomo no tame ni - For the Sake of the Children: The Japanese American Experience in Hawaii, Honolulu 1978, s. 209-217.

10 Wielką Piątkę tworzyły: Alexander \& Baldwin, American Factors, Castle \& Cook, C. Brewer \& Co., Theo H. Davies \& Co. Wymienione korporacje wywierały znaczny wpływ na sytuację polityczno-ekonomiczną Hawajów jak i samych Japończyków; zob. N. J. Kent, Hawaii: Islands under the Influence, Honolulu 1993, s. 69-91.

11 R. A. Wilson, W. K. Hosokawa, East to America: A History of the Japanese in the United States, New York 1982, s. 151. Szerzej na temat strajku w 1920 i jego konsekwencji: M. U. Duus, The Japanese Conspiracy: The Oahu Sugar Strike of 1920, Berkeley-Los Angeles 1999. 
tego rozdarcia była kwestia posiadania podwójnego obywatelstwa. Brak dokładnych danych obrazujących skalę zjawiska, z pewnością jednak odsetek Nisei posiadających obywatelstwo japońskie był zróżnicowany pod względem miejsca zamieszkania. Według szacunków rządu japońskiego w 1930 roku posiadało je $47 \%$ Nisei zamieszkałych w Kalifornii ${ }^{12}$. Na Hawajach odsetek był znacznie wyższy, większość Nisei posiadała japońskie obywatelstwo, w 1940 roku 73 ze 119 tys. (ponad 60\%)13. Odsetek ten z czasem zapewne zmniejszyłby się, o czym świadczy spadek liczby dzieci rejestrowanych w placówkach dyplomatycznych Japonii, co zgodnie z obowiązującym od 1924 roku prawem było konieczne dla uzyskania przez nie obywatelstwa. Na Hawajach w latach 1924-1933 zarejestrowano 40\% narodzonych Nisei, w 1939 roku jedynie 25\% ${ }^{14}$. Równocześnie pewna liczba Nisei rezygnowała z posiadania obywatelstwa japońskiego, co miało być m.in. symbolicznym aktem zerwania z Japonią i stania się stuprocentowym Amerykaninem (akcję zrzekania się obywatelstwa japońskiego często wspierali także Issei) ${ }^{15}$.

Drugą oznaką rozdarcia Nisei pomiędzy Japonię i Stany Zjednoczone była kwestia używanego języka. Issei, w większości słabo znający język angielski, uważali, że ich dzieci powinny władać tym językiem, w takim stopniu jak Amerykanie. Doskonała znajomość języka miała umożliwić stanie się pełnoprawnymi członkami społeczeństwa. Zarazem, za konieczne najstarsza generacja uważała posiadanie znajomości języka japońskiego, potrzebnego do poznania i zachowania dziedzictwa narodowego i tożsamości. Dodatkowo brano pod uwagę nieokreśloną w czasie możliwość lub nawet konieczność powrotu do Japonii. W konsekwencji Nisei chodzili do dwóch szkół, w których uczyli się dwóch języków. Tak jak ich rówieśnicy, uczęszczali do szkoły, w której porozumiewano i uczono się wyłącznie języka angielskiego. Po południu natomiast większość z nich uczyła się języka japońskiego w szkole prywatnej. Rezultatem było powstanie trudności komunikacyjnych pomiędzy obu generacjami ${ }^{16}$. Pomimo niskiej efektywności nauczania języka japońskiego i działań administracji stanowej, mających na celu

${ }^{12}$ Ch. M. Lyon, Dual citizenship, http://encyclopedia.densho.org/Dual_citizenship/, [dostęp 23.02. 2015].

13 J. J.Stephan, Hawaii Under the Rising Sun: Japan's Plans for Conquest after Pearl Harbor, Honolulu 2002, s. 23.

14 Ibidem, s. 24, E. H. Tamura, Americanization, Acculturation and Ethnic Identity: The Nisei Generation in Hawaii, Urbana-Chicago 1994, s. 86.

15 Ibidem, s. 84 i n.

16 Zob. B. Hosokawa, op. cit., s. 158 i n., E. H. Tamura, op. cit., s. 156-157. Dla części Nisei, nauka języka japońskiego była niechcianym doświadczeniem, narzuconym przez rodzinę, zob. wywiady: George Yoshida, wywiad przeprowadzili A. Ito, J. Pai, 18 lutego 2002; Hiro Nishimura, wywiad przeprowadził T. Ikeda, 28 kwietnia 2009; wywiady w: Densho Visual History Collection, Densho, archive.densho.org. 
ograniczenie zasięgu jego nauczania, większość Nisei była nim objęta. Na Hawajach, zasięg był szerszy, na początku lat trzydziestych $87 \%$ tamtejszych Nisei uczęszczało do japońskich szkół językowych ${ }^{17}$. Obawy Amerykanów, dotyczące ich wpływu na Nisei były częściowo uzasadnione. Niektóre japońskie szkoły, oprócz wpajania uczniom takich zasad jak pracowitość i szacunek dla ładu społecznego, uczyły także japońskiego nacjonalizmu ${ }^{18}$.

Podwójne szkolnictwo powodowało także inne problemy. Szkoła amerykańska wszczepiała uczniom wartości często diametralnie różne od przekazywanych Nisei w domu czy szkole japońskiej, co pogłębiało rozdźwięk pomiędzy pokoleniami. Tak o tej sytuacji pisał przedstawiciel drugiej generacji, Bill Hosokawa:

w szkole Nisei byli uczeni zadawania pytań i kwestionowania, zachęcani do podejmowania własnych decyzji, bycia agresywnymi, potwierdzania własnej indywidualności [...] rodzice, którzy w domu uczyli oddawania czci, szacunku i posłuszeństwa, jednocześnie wzywali Nisei do oddawania czci, szacunku i posłuszeństwa nauczycielom, którzy automatycznie i nieumyślnie indoktrynowali młodzież sprzeczną filozofią ${ }^{19}$.

Znaczenie szkoły w procesie amerykanizacji było nie do przecenienia, co przyznawali sami Nisei. Florence Akiyama, w mowie na zakończenie szkoły średniej stwierdziła: „nauka w szkole średniej oznacza chłonięcie amerykańskiego ducha. Mam tu na myśli nie tylko nastawienie wobec Ameryki, ale także zwyczaje i wrodzoną zdolność do mówienia i myślenia w języku angielskim" ${ }^{20}$.

Według Issei, znajomość języka angielskiego nie była wystarczająca do osiągnięcia ugruntowanej pozycji społecznej. Bardzo duży nacisk kładziono na uzyskiwanie jak najlepszych wyników w nauce i jak najlepszego wykształcenia. Jak tłumaczył Issei z Hawajów, edukacja miała być przepustką do lepszego życia: „niektórzy z nas są biedni, ale wysyłamy nasze dzieci do szkół - szkół średnich a nawet wyższych, ponieważ nie chcemy dla nich takiego życia jak nasze"21. Szanse, jakie stwarzała edukacja i amerykańskie szkolnictwo były doceniane także przez Nisei. W rezultacie poświęcali oni na edukację wiele czasu i wysiłku. W Kalifornii, dla Nisei w wieku co najmniej 25 lat, mediana czasu trwania

17 E. H. Tamura, op. cit., s. 146. Szerzej o japońskich szkołach językowych s. 146-161; E. Azuma, Race, History and Transnationalism in Japanese America, New York 2005, s. 122 i n.

18 Zob. np. wspomnienia: D. K. Inouye with L. Elliot, Journey to Washington, Englewood Cliffs 1967, s. 36-37.

19 B. Hosokawa, op. cit., s. 172.

20 F. Akiyama, What High School Means to a Japanese Girl, [w:] Nisei Voices: Japanese American Students of the 1930s - Then \& Now, (red.) J. Hirohata, P. T. Hirohata, San Jose 2004, s. 107.

21 Cyt. za E. H. Tamura, op. cit., s. 97. 
kształcenia wynosiła 12,2 lat, a więc była wyższa niż w przypadku Kalifornijczyków w analogicznym przedziale wiekowym (9,9 lat) i Amerykanów w skali kraju (8,6 lat) ${ }^{22}$. Uczyli się w dodatku z sukcesami. Jak wspominał Ben Uyeno, w trzech szkołach średnich w Seattle w latach trzydziestych, pierwszą dziesiątkę najlepszych uczniów tworzyli Japończycy ${ }^{23}$.

Specyficzną częścią społeczności japońskiej byli Kibei: Nisei, a więc urodzeni w Stanach Zjednoczonych, ale przebywający przez część swojego życia w Japonii. Powodów wyjazdu do kraju rodziców było kilka. Podstawowym było uzyskanie odpowiedniego, japońskiego wychowania i edukacji. Innymi były trudności finansowe lub śmierć matki. Czasami wyjeżdżano już po szkole średniej, by uzyskać wyższe wykształcenie. Grupa ta liczyła ok. 10-20 tys. osób. Pobyt w Japonii powodował, że wielu Kibei czuło się bardziej związanych z nią niż ze Stanami Zjednoczonymi, a z powodu słabej znajomości języka angielskiego silniejsze więzi łączyły ich z Issei niż Nisei. Ponadto, doświadczenie życiowe Kibei było najbliższe Yobiyose, czyli Issei urodzonym w Japonii, ale wychowanym w USA ${ }^{24}$.

Społeczeństwo japońskie w Stanach Zjednoczonych było podzielone również pod względem wyznaniowym. Na Terytorium Hawajów, gdzie Japończycy stanowili dużą część mieszkańców, łatwiej było zachować spoistość kulturową i tradycję, w tym także religię. Pomimo wielu zastrzeżeń wysuwanych przez Amerykanów, według których bycie Amerykaninem jest równoznaczne z byciem chrześcijaninem, dominującą religią wśród Japończyków pozostał buddyzm. W 1937 roku wspólnoty buddyjskie miały blisko 40 tys. zarejestrowanych członków, w 1941 roku liczba ta zwiększyła się do ok. 50 tys., czyli 35\% całej tamtejszej społeczności japońskiej. W rzeczywistości odsetek buddystów był wyższy, gdyż nie wszyscy wyznawcy byli zarejestrowani. Konwersje na chrześcijaństwo nie były liczne, w 1937 roku zaledwie ok. 2,5 tys. Japończyków należało do Kościołów protestanckich, a katolików było jeszcze mniejej.

W kontynentalnej części USA większość społeczeństwa japońskiego także wyznawała buddyzm, choć były takie miejsca jak Seattle, gdzie w latach trzydziestych XX wieku dominowało chrześcijaństwo. Odsetek chrześcijan był znacznie wyższy niż na Hawajach. Brakuje dokładnych danych liczbowych, jednak z pew-

22 Personal Justice Denied: Report of the Commission on Wartime Relocation and Internment of Civilians, Commission on Wartime Relocation and Internment of Civilians, Seattle 1997 (I wydanie 1982), s. 43-44.

23 Ben Uyeno, wywiad przeprowadził D. Goto, 1 czerwca 1998, Densho Visual History Collection, Densho.

24 R. A. Wilson, W. K. Hosokawa, op. cit., s. 166-167; M. Jin, Beyond Two Homelands: Migration and Transnationalism of Japanese Americans in the Pacific, 1930-1955, s. 3-4, 100, praca doktorska, Santa Cruz, University of California 2013, nieopublikowana, escholarship.org, [dostęp 20.02.2015]. Praca Jina jest pierwszą monografią szeroko opisującą doświadczenia Kibei.

25 E. H. Tamura, op. cit., s. 203-210. 
nością wśród chrześcijan przeważali Nisei. Część konwersji z buddyzmu wynikała z potrzeby akceptacji społecznej, jednak wśród chrześcijan Issei byli też i ci, którzy zostali nimi jeszcze w kraju pochodzenia ${ }^{26}$.

Posługując się przykładem Kalifornii, można wysunąć wniosek, że Japończycy przed II wojną światową nie odbiegali znacząco zamożnością od społeczności amerykańskiej. W 1940 roku mediana dochodu Japończyków wynosiła 622 dolary. Było to wprawdzie mniej niż mediana stanu, która wynosiła 852 dolary, ale niemal dokładnie tyle samo ile wynosiła krajowa, czyli 627 dolarów. Społeczność japońską cechowało natomiast bardzo niskie bezrobocie. W 1940 roku zatrudnionych było 96,7\% Japończyków zdolnych do pracy; był to odsetek znacznie wyższy od stanowego, wynoszącego 85,6\%. Tak wysoki stopień zatrudnienia wynikał w dużej mierze z kultury japońskiej, kładącej nacisk na pracowitość. Japończykom udawało się osiągać dobre wyniki finansowe, pomimo kłopotów w rolnictwie, wciąż będącym dla nich podstawowym miejscem zatrudnienia. Zmniejszanie areału uprawianej ziemi i spadek cen w okresie wielkiego kryzysu spowodowały, że wartość produkcji roślinnej wyniosła w 1941 roku 32 mln dolarów, a więc znacznie mniej niż np. podczas I wojny światowej (55 mln dolarów). Japońska produkcja rolna, o czym świadczą statystyki wciąż była istotną częścią produkcji rolnej stanu ${ }^{27}$. Poza rolnictwem w większej liczbie Japończycy pracowali głównie w rybołówstwie, ogrodnictwie, jako pomoc domowa i prowadząc własne sklepy czy punkty usługowe. Wzrastała także liczba Nisei pracujących na stanowiskach wymagających wyższych kwalifikacji i w administracji, choć w wyniku nierzadkiej dyskryminacji przy zatrudnianiu, możliwości znalezienia dobrej pracy były ograniczone ${ }^{28}$. Pod tym względem lepiej przedstawiała się sytuacja na Hawajach. Pomimo że Japończycy w dalszym ciągu stanowili tam znaczną część robotników pracujących na plantacjach, byli zatrudnieni w większej liczbie także w wielu innych branżach, również jako pracownicy umysłowi ${ }^{29}$.

W latach trzydziestych XX wieku bardzo duża część Nisei osiągała pełnoletność, a zarazem pełne prawa wyborcze. Zamierzali oni je wykorzystać do wywarcia wpływu na władze lokalne i federalne, w celu zademonstrowania swojego

26 B. Hosokawa, op. cit., s. 126-132; zob. także: D. K. Yoo, Growing up Nisei: Race, Generation, and Culture among Japanese American of California, 1924-1949, Urbana 2000, s. 38-67.

27 Personal..., s. 43-44; W 1939 roku w północnej Kalifornii Japończycy wyprodukowali m.in. $97 \%$ jagód, $82 \%$ cebuli i $59 \%$ selera. W tym samym roku w południowej Kalifornii m.in. $96 \%$ kalafiora i 83\% pomidorów; E. Azuma, op. cit., s. 113-114. Podczas kryzysu gospodarczego ucierpieli rolnicy różnego pochodzenia narodowego, np. Meksykanie, a zyski z produkcji rolnej w Kalifornii spadły z 750 milionów w 1929 roku do 327 milionów dolarów w 1932 roku, V. Matsumoto, Farming a Home Place: Japanese American Community in California, 1919-1982, Ithaca 1993, s. 58.

28 Personal, s. 43-44, B. Hosokawa, op. cit., s. 166-167.

29 E. H. Tamura, op. cit., s. 216 i n. 
zaangażowania obywatelskiego i obrony własnych interesów. Pomóc w tym miały organizacje, wśród których czołowe miejsce zajmowała utworzona w 1929 roku Japanese American Citizens League (JACL). Powstała ona, opierając się na trzech istniejących wcześniej: American Loyalty League z Fresno, Progressive Citizens League z Seattle i New American Citizen League z siedzibą w San Francisco ${ }^{30}$. Przez całą dekadę rozbudowywała swoje struktury, starając się swoim oddziaływaniem objąć jak największe kręgi japońskiego społeczeństwa. Jednocześnie aktywnie włączyła się w kampanię na rzecz uchwalenia poprawki do Cable Act of 1922 (Married Women's Independent Nationality Act) i udzielała wsparcia kampanii na rzecz przyznania obywatelstwa weteranom I wojny światowej z generacji Issei.

Zgodnie z ustawą kobiety, które wyszły za mąż za cudzoziemców traciły obywatelstwo amerykańskie. Mogły je odzyskać przez naturalizację, w przypadku zakończenia trwania małżeństwa (rozwód, anulowanie lub śmierć). Taka możliwość była zamknięta dla Japonek, z racji przynależności do narodu pozbawionego prawa do naturalizacji. Przeciwko dyskryminacji agitowała JACL (dalej także: Liga), wysyłając nawet delegata do Waszyngtonu - młodą działaczkę Suma Sugi. Dyskusja wokół ustawy zakończyła się po myśli Ligi, uchwaleniem poprawki, zgodnie z którą kobiety nie traciły obywatelstwa z powodu małżeństwa. Mimo aktywności JACL i Sugi, która spotkała się z senatorem Johnem Cable, ich wkład w przyjęcie poprawki przez Kongres i podpisanie przez Prezydenta Herberta Hoovera 3 marca 1931 roku był raczej nieduży. Znacznie większe znaczenie miały wystąienia organizacji kobiecych, takich jak League of Women Voters czy Young Women's Christian Association, które protestowały przeciwko dyskryminacji kobiet, w tym przypadku szczęśliwie dla bezpośrednio zainteresowanych połączonej z dyskryminacją rasową ${ }^{31}$.

Japanese American Citizens League miała swój udział także w uchwaleniu przez Kongres ustawy Nya-Lea, podpisanej przez Prezydenta Franklina D. Roosevelta 25 czerwca 1935 roku. Dzięki tej ustawie weterani I wojny światowej pochodzący z narodów niekwalifikujących się do obywatelstwa mogli je uzyskać. Sprawa obywatelstwa dla weteranów jest ściśle powiązana z osobą Tocutaro Slocuma. Urodzony w Japonii, ale wychowany w Stanach Zjednoczonych, ochotnik z czasów wielkiej wojny, rozpoczął walkę o uzyskanie obywatelstwa tuż po jej zakończeniu w grudniu 1918 roku. Poparcie Slocuma przez Ligę, miało wskutek ograniczonych możliwości finansowych wartość przede wszystkim moralną. Sama Liga, zdaje się, nie odegrała w tej kampanii decydującej roli. O jej sukcesie zadecydowało powszechne poparcie udzielone m.in. przez American Legion,

\footnotetext{
30 Na temat Ligi: B. Hosokawa, JACL: in Quest of Justice. The History of the Japanese American Citizens League, New York 1982.

31 Ibidem, s. 42-44, 48-51.
} 
Veterans of Foreign Wars i California Joint Immigration Commitee. Niemniej ustawa została słusznie uznana przez JACL za sukces i krok na drodze do uzyskania prawa do naturalizacji ${ }^{32}$.

Omawiana dekada była czasem sukcesów Nisei także na innym polu. W 1930 roku po raz pierwszy skutecznie wystartowali w wyborach. Demokrata Andy Yamashiro i republikanin Takasu Oka zostali wówczas członkami Izby Reprezentantów Terytorium Hawajów. W 1936 roku we władzach ustawodawczych Terytorium znajdowało się już 9 polityków japońskiego pochodzenia ${ }^{33}$. Powodów do radości dostarczyły hawajskim Nisei ostatnie przed wybuchem wojny wybory. W 1940 roku, po burzliwej kampanii, podczas której jednym z głównych tematów było podwójne obywatelstwo, po raz pierwszy senatorem został Japończyk, były policjant Sanji Abe ${ }^{34}$. W tym samym roku Japończycy stanowili na Hawajach 14,3\% wszystkich wybieranych urzędników i 2,9\% pochodzących z nominacji ${ }^{35}$. Pomimo prób, Nisei nie udało się osiągnąć żadnego sukcesu wyborczego na kontynencie, ponieważ ich potencjał wyborczy był tam znacznie niższy. Było to w dużym stopniu odzwierciedleniem sytuacji demograficznej. Na Hawajach, udział Japończyków w grupie osób uprawnionych do głosowania był znacznie wyższy i wynosił 13\% w 1930 i aż 31\% w 1940 roku $^{36}$.

Działalność Nisei powodowała sprzeciw ze strony Issei. Starsze pokolenie było niechętne wszechobecnemu podkreślaniu amerykańskości przez Nisei, wysuwało zarzuty o odejściu od kultury japońskiej i uznawało Ligę za konkurenta w przewodzeniu społeczności. Częściowo interesy obu generacji rzeczywiście były rozbieżne, co wynikało $\mathrm{z}$ ich odmiennego statusu prawnego, tożsamości kulturowej i doświadczeń życiowych. Issei, choć chcieli, by ich dzieci były pełnoprawnymi Amerykanami, oczekiwali zarazem, że nie rozluźni to silnych związków z narodem japońskim. Wielu z nich widziało Nisei jako Amerykanów będących pomostem pomiędzy Japonią i Stanami Zjednoczonymi, objaśniających i przybliżających innym Amerykanom Japonię, jej kulturę, historię, ale także działania na arenie międzynarodowej. Koncepcja ta, bridge of understanding była propagowana także przez część Nisei, z czołowym działaczem JACL i redaktorem „Japanese-American Courier”, Jamesem Sakamoto na czele. W latach trzydziestych zainteresowanie tą koncepcją, a ściślej wykorzystaniem Nisei jako rzeczników własnej polityki, wykazał rząd japoński. Większość Nisei odnosiła

32 Ibidem, s. 51-56; zob. także: L. E. Salyer, Baptism by Fire: Race, Military Service and U.S. Citizenship Policy, 1918-1935, "Journal of American History" 2004, t. 91, nr 3, s. 847-876;

B. Niiya, Tokutaro Slocum, http://encyclopedia.densho.org/Tokutaro\%20Slocum//

33 B. Hosokawa, JACL..., s. 79.

34 Kelli Y. Nakamura, Sanji Abe, http://encyclopedia.densho.org/Sanji_Abe//, [dostęp 19.02.2015].

35 E. H. Tamura, op. cit., s. 227.

36 E. C. Nordyke, Y. S. Matsumoto, op. cit., s. 166. 
się jednak do niej z dystansem ${ }^{37}$. Występowały także inne różnice pomiędzy obu generacjami, jak np. odmienna działalność organizacji. Struktura organizacji Issei, w przeciwieństwie do JACL, powiązana była od początku z państwem japońskim, a działalność ukierunkowana tak, by nie szkodzić jego interesom. Zależność organizacji wprawdzie z czasem stawała się mniejsza, jednak wydarzenia międzynarodowe lat trzydziestych sprawiły, że działalność na rzecz Imperium Japońskiego była jednym $z$ istotniejszych elementów ${ }^{38}$. Issei nie skupiali się jednak wyłącznie na niej, zwłaszcza że uwagi wymagała sprawa zachowania i rozwoju własnego dorobku i pozycji ekonomicznej. Jednym z ich największych zmartwień była sprawa dziedziczenia farm przez Nisei. Młodsza generacja była znacznie mniej entuzjastycznie nastawiona do pracy na roli i jak wskazywali sami Issei, wolała mieszkać $\mathrm{w}$ miastach i wykonywać zawody z grupy white collar. W celu przeciwdziałania tym trendom Issei stworzyli specjalny program Back-to-the-Farm (Kino undo), funkcjonujący od 1935. Obejmował on szereg działań, zarówno praktycznych np. organizowanie specjalistycznych kursów rolniczych, jak i propagandowych, promujących rolnictwo i życie na wsi jako najbardziej wartościowy model życia (wymownym tego przykładem może być film z 1936 roku The Growing Nisei). Starano się także włączyć Nisei w struktury organizacji rolniczych, co ostatecznie zakończyło się sukcesem, gdy w kwietniu 1940 roku została utworzona Nisei Farmers Federation of California. Brakuje dokładnych danych przedstawiających skuteczność kampanii, w każdym razie zmiana pokoleniowa wśród rolników odbywała się bez przeszkód ${ }^{39}$.

Z Back-to-the-Farm Movement powiązana była kampania Return-to-America (Kibei undo). Prowadzona od 1935 roku miała na celu przekonanie Kibei do powrotu do Stanów Zjednoczonych i podejmowania pracy na farmach Issei. Powrót ten miał być konieczny do zachowania pozycji wywalczonej w rolnictwie przez imigrantów z pierwszego pokolenia. Powodem takiego przekonania było znaczne zmniejszanie się japońskiej siły roboczej. Brak nowych imigrantów i przemieszczanie się Nisei do miast oraz innych zawodów, w końcu wyjazdy do Japonii, miały prowadzić według Issei do wypierania Japończyków przez farmerów pochodzenia filipińskiego i meksykańskiego. Twierdzili oni, że zachodziła analogia

37 Y. Ichioka, „Dai Nisei Mondai”: Changing Japanese Immigrant Conceptions of the Second Generation Problem, 1902-1941, [w:] Before Internment: Essays in Prewar Japanese American History, (red.) G. H. Chang, E. Azuma, Stanford 2006, s. 24-43; E. Azuma, op. cit., s. 145-151.

38 Zob. Y. Ichioka, The Issei..., s. 156-164. Działalność Issei, także ta mająca na celu promowanie języka i kultury japońskiej spowodowała, że wiele ich organizacji znalazło się w 1941 roku na liście organizacji niebezpiecznych dla państwa, stworzonej przez Office of Naval Intelligence (ONI); B. Kumamoto, The Search for Spies: American Counterintelligence and the Japanese American Community 1931-1942, "Amerasia Journal" 1979, t. 6, nr 2, s. 61 i n., MetaPress, [dostęp 12.03.2015].

39 E. Azuma, op. cit., s. 114-118. 
do sytuacji z końca XIX wieku, gdy Chińczycy, pozbawieni dopływu siły roboczej z powodu ustawy zakazującej imigracji rodaków do Stanów Zjednoczonych, przegrali rywalizację właśnie $\mathrm{z}$ nimi. W ramach kampanii prowadzono w Japonii działalność informacyjno-propagandową (wydano np. Guide to Returning to America), wysyłano do Japonii delegatów mających zarówno przekonywać Kibei do powrotu, jak i władze japońskie do wsparcia akcji (choć bezskutecznie). Nierzadko poszczególne organizacje Issei i nawet poszczególni farmerzy wspomagali finansowo powrót Kibei. Kampania szybko przyniosła rezultaty, bowiem liczba powracających wzrosła znacznie już w 1936 roku. W następnych latach wzrost był jeszcze wyższy, co miało związek z agresją Japonii na Chiny i chęcią uniknięcia powołania do wojska przez Kibei posiadających obywatelstwo japońskie ${ }^{40}$.

Zaatakowanie Chin przez Japonię, sprawiło że Nikkei bardzo wiele energii poświęcili na wspieranie kraju Cesarza. Bardzo duże wzmocnienie postaw nacjonalistycznych nastąpiło zarówno na Zachodnim Wybrzeżu, jak i na Hawajach.

Na Hawajach, w dekadzie poprzedzającej wojnę, uczucia projapońskie były silne i pielęgnowane, zwłaszcza przez Issei (ok. 40 tys. osób). Sytuacja ta, w zasadzie całkowicie zrozumiała, przekładała się jednak także na całkowite i konsekwentne poparcie polityki zagranicznej Imperium. Przejawiało się ono na kilka sposobów, w tym było stale obecne w prasie japońskojęzycznej. Najbardziej wpływowe gazety wydawane przez Japończyków („Nippu jiji”, „Hawaii hochi” i „Jitsugyo no Hawaii”) aż do Pearl Harbor uznawały japońskie działania za słuszne i jedynie źle rozumiane w Stanach Zjednoczonych. Krytycznie pisano o mocarstwach kolonialnych, a zwłaszcza Związku Sowieckim. Pozytywnie natomiast o faszystowskich Włoszech i nazistowskich Niemczech, z co najmniej sympatią odnosząc się do kolejnych poczynań Hitlera (Anschlussu Austrii i zajęcia Czechosłowacji). Poparcie dla polityki japońskiej, a szczególnie wojny w Chinach, były jednak w pewien sposób maskowane. Jak zwrócił uwagę John J. Stephan, anglojęzyczne i japońskojęzyczne rubryki prasy japońskiej, opisując te same wydarzenia, używały różnych określeń, np. odpowiednio „armia japońska” i „nasza armia”. Za wiarygodne źródło informacji uznawano japońską agencję informacyjną Domei, natomiast wszystkie niekorzystne dla Imperium wiadomości i opinie uznawano za „chińską propagandę" ${ }^{41}$. W prasie regularnie zachęcano do wspierania wysiłku wojennego Imperium, co w połączeniu z innymi czynnikami przyniosło znaczny rezultat. Japończycy mieszkający na Hawajach wykupili w latach 1937-1939 obligacje wojenne na kwotę 3 mln jenów (880 tys. dolarów) i przekazali 1,2 mln jenów (350 tys. dolarów) na National Defense and Soldier's Relief Fund ${ }^{42}$.

40 Ibidem, s. 119-122.

41 J. J. Stephen, op. cit., s. 26-29.

42 Ibidem, s. 33. 
Nisei (prawdopodobnie z przewagą Kibei) walczyli także w Chinach jako ochotnicy i poborowi. Ich dokładna liczba nie jest znana, z pewnością jednak nie były to odosobnione przypadki ${ }^{43}$. Ofiarna działalność Issei i Nisei była zauważona i doceniona przez wysokich przedstawicieli japońskich władz, w tym ministra marynarki Mitsumasu Yonai i ministra armii gen. Sugiyamę ${ }^{44}$. Kontakty Japończyków z Hawajów z krajem przodków były przez cały omawiany okres podtrzymywane poprzez wizyty japońskich przedstawicieli polityki, wojska czy prasy oraz regularne pobyty japońskich okrętów wojennych.

Sytuacja w kontynentalnej części Stanów Zjednoczonych była pod wieloma względami bardzo podobna do tej na Hawajach. Społeczność japońska, przede wszystkim Issei, w mały stopniu Nisei, popierała wojnę z Chinami i inne działania Cesarstwa. Wsparcie przejawiało się na kilka sposobów. Jednym z istotniejszych była zbiórka pieniędzy przeznaczonych na fundusz wojenny i pomoc wojenną. Kwota przesłana do Japonii była wyższa od tej przesłanej przez Japończyków z Hawajów. Środki gromadzono nierzadko bardzo ofiarnie, np. miejscowość w stanie Waszyngton, Yakima, licząca zaledwie 814 mieszkańców, zebrała pomiędzy sierpniem 1937 a marcem 1939 roku 5775 dolarów. Pod kierownictwem i przy pomocy przedstawicieli państwa japońskiego, prowadzono także ożywioną działalność propagandową w społeczeństwie amerykańskim i w mniejszym stopniu także wśród Nisei. Polegała ona przede wszystkim na rozpowszechnianiu publikacji przedstawiających japoński punkt widzenia na wojnę w Chinach. Większość $\mathrm{z}$ nich rozchodziła się w kilkudziesięciotysięcznym nakładzie na Zachodnim Wybrzeżu, część jednak także w Chicago i Nowym Jorku. Dużą rolę w ich rozpowszechnianiu, zgodnie z koncepcją people's diplomacy odgrywali zwykli Japończycy, kolportujący materiały w swoim otoczeniu, np. miejscu pracy, kościele czy szkole. Bardzo aktywna była także część Nisei, m.in. z pomocą działaczy JACL z Los Angeles utworzono English Speaker's Bureau przekształcone następnie w Far Eastern Research Institute, instytucję, która miała za zadanie przekonywać Amerykanów do japońskiego sposobu patrzenia na sytuację na Dalekim Wschodzie. Poparcie wyrażano również poprzez patriotyczne uroczystości organizowane w celu uczczenia kolejnych sukcesów w Chinach, wysyłanie paczek na front, twórczość literacką i zakładanie organizacji patriotycznych. Było ono widoczne także w prasie, która japońską politykę przedstawiała w korzystnym świetle. Tak jak na Hawajach, za wiarygodne uznawano wyłącznie japońskie źródła informacji, natomiast antyjapońskie nastawienie amerykańskiej opinii publicznej i prasy uważano za niesprawiedliwe, co częściowo można wytłumaczyć brakiem wiedzy ${ }^{45}$.

43 Ibidem, s. 35 i n.

44 Ibidem, s. 34.

45 E. Azuma, op. cit., s. 163-183; Y. Ichioka, Japanese Immigrant Nationalism: The Issei and the Sino-Japanese War, 1937-1941, "California History" 1989, t. 69, nr 3 (Fall), s. 260-275, JSTOR, [dostęp 08.03.2015]. 
Japonia otrzymywała wsparcie na łamach prasy także od Kibei. Dziennikarze „Kashu Mainichi”, Sei Fuji i Akira Itami nie tylko usprawiedliwiali poczynania Cesarstwa jako antysowieckie, ale także bagatelizowali możliwość wybuchu wojny amerykańsko-japońskiej i w ogóle przystąpienia Stanów Zjednoczonych do wojny. Nietrafne rozeznanie sytuacji międzynarodowej prowadziło m.in. do uznania (styczeń 1940) podejmowanych przez rząd amerykański działań wzmacniających potencjał militarny na Pacyfiku nie za przygotowania do wojny z Japonią, ale uderzenia na dalekowschodnią część ZSRR, co miałoby zapobiec rozprzestrzenianiu komunizmu. Przynajmniej w początkowej fazie wojny, pozytywnie pisano o pozostałych państwach $\mathrm{Osi}^{46}$.

Patriotyczne poparcie kraju pochodzenia można uznać za coś naturalnego i nie powinno być potępiane. Podobnie postępowali także Amerykanie pochodzenia np. polskiego czy włoskiego. Jednak Japonia była w tym przypadku agresorem, a traktowanie wszystkich niekorzystnych dla niej opinii i wiadomości jako „chińskiej propagandy” skłania do zastanowienia, zwłaszcza w obliczu brutalności armii japońskiej, np. masakry nankińskiej. Prasa amerykańska informowała o tym wydarzeniu ${ }^{47}$, a jedynym wytłumaczeniem dla Issei, mogą być trudności językowe uniemożliwiające swobodną lekturę w języku angielskim.

Rozwój konfliktu amerykańsko-japońskiego w znaczący sposób wpłynął na postawy społeczności japońskiej. Pokolenie Nisei, zwłaszcza na kontynencie, już wcześniej cechował zdystansowany stosunek do Japonii, a więc i do jej polityki zagranicznej. W obliczu możliwej wojny bardziej otwarcie opowiadano się po stronie kraju urodzenia. Natomiast JACL nie popierała agresji japońskiej w Chinach i deklarowała wolę obrony Stanów Zjednoczonych przed jakimkolwiek zewnętrznym zagrożeniem. O całkowitej lojalności zapewniał na konwencji Ligi w Portland w 1940 roku jej Prezydent Walter Tsukamoto, zapewnienia o wierności znalazły się także w uchwalonej rezolucji. Co więcej, JACL deklarowała współpracę przy realizacji Alien Registration Act ${ }^{48}$. Działacze Ligi zaczęli wyraźniej dystansować się nie tylko od głębszych związków z Japonią, ale także, ze starszą generacją i jej organizacjami. Nowy Prezydent Saburo Kido odrzucił, zarówno możliwość wzięcia udziału w uroczystościach 2600 rocznicy założenia Japonii, na które otrzymał zaproszenie władz japońskich, jak i przeprowadzenia wspólnej, wraz z organizacją Issei, Japanese Association of North America kampanii zbierania funduszy (pomimo trudności finansowych Ligi) ${ }^{49}$. W uroczy-

\footnotetext{
46 M. Jin, op. cit., s. 96-97, 105-109. Akira Itami był wówczas wiceprezesem Wydziału Kibei w oddziale JACL w Los Angeles.

47 Zob. S. Lu, The Nanjing Atrocities Reported in the U.S. Newspapers, 1937-38, http://www.re adex.com/readex-report/nanjing-atrocities-reported-u-s-newspapers-1937-38, [dostęp 11.03.2015].

48 B. Hosokawa, JACL..., s. 105-107.

49 Ibidem, s. 125-126.
} 
stościach milenijnych wzięli udział Issei z kontynentu i z Hawajów, wysyłając delegacje liczące łącznie kilkaset osób ${ }^{50}$.

Przybliżanie się perspektywy uczestnictwa Stanów Zjednoczonych w wojnie światowej oraz wojny z Japonią, wywoływały wśród amerykańskiego społeczeństwa, polityków i wojskowych pytania o stanowisko, jakie zajmą w tym konflikcie Japończycy zamieszkujący państwo. Pojawiały się wątpliwości, co do lojalności obywateli japońskich, Issei. Za szczególne zagrożenie uważano Kibei, którzy, jak akcentowano, pod wieloma względami bliżsi byli Japonii niż Stanom Zjednoczonym ${ }^{51}$. Powszechnie obawiano się szpiegostwa i sabotażu, a nierzadko wszystkich Japończyków bez stosowania jakichkolwiek podziałów postrzegano jako zagrożenie. Zarzuty nielojalności miały szczególne znaczenie na Hawajach, gdzie od 1935 roku odbywały się przesłuchania przed komisją Kongresu w sprawie nadania terytoriom statusu stanu. Biali Amerykanie starali się przeciwdziałać takiej możliwości, twierdząc, że skutkować ona będzie przejęciem władzy przez oddanych Cesarzowi Japończyków, co miało stanowić zagrożenie dla bezpieczeństwa Stanów Zjednoczonych ${ }^{52}$.

Strach i zarzuty o nielojalność obecne były w powszechnie dostępnej literaturze. W opublikowanej w 1938 roku książce Children of the Rising Sun, Willard Price, popularny amerykański pisarz pochodzenia kanadyjskiego, napisał, że Japończycy mają w sercach zapisaną lojalność do Cesarza, której nie można usunąć w ciągu ledwie kilku pokoleń ${ }^{53}$. Pojawiały się także ostrzejsze twierdzenia. Blayney Matthews w swojej książce The Spectre of Sabotage z 1941 roku pytał: ,what is to prevent japanese spies, in their fanatical zeal from striking a blow for their emperor by excessively dusting vegetables with arsenic?" ${ }_{54}$.

Strach przed japońskim szpiegostwem i sabotażem, przeprowadzanymi przy współudziale Japończyków zamieszkałych w Stanach Zjednoczonych, zwłaszcza na Zachodnim Wybrzeżu, był duży i nieadekwatny do sytuacji. Możliwości posługiwania się przez Imperium Japończykami mieszkającymi w Stanach Zjednoczonych były bardzo ograniczone. Na kontynencie liczebność, rozmieszczenie i wykonywane zawody bardzo utrudniały amerykańskim Japończykom przeprowadzanie aktów sabotażu. Większe, choć również ograniczone możliwości, istniały w zakresie szpiegostwa, choć i w tym przypadku z powodu zewnętrznych różnic rasowych Japończycy bazowali w większym stopniu nie na swoich ro-

\footnotetext{
50 J. J. Stephen, op. cit., s. 49; Y. Ichioka, Japanese Immigrant..., s. 270-273.

51 ONI stworzyła listę jedenastu niekorzystnych cech charakteryzujących Kibei, m.in. brak amerykańskiej edukacji, brak znajomości języka angielskiego, podwójne obywatelstwo, B. Kumamoto, op. cit., s. 64.

52 Zob. zeznanie Johna F. G. Stokesa przed Joint Commitee on Hawaii Statehood, październik 1937, przedrukowane w: D. Ogawa, op. cit., s. 256-264.

53 Zob. E. Azuma, op. cit., s. 4.

${ }^{54}$ Cyt. za: B. Kumamoto, op. cit., s. 61.
} 
dakach mieszkających w USA, lecz na białych Amerykanach (czego dowiodły sprawy Harry'ego Thompsona i Johna S. Farnswortha z 1936 roku). Dzięki włamaniu do konsulatu japońskiego w Los Angeles w marcu 1941 roku, FBI i ONI rozbiły kolejną siatkę szpiegowską, która do pozyskiwania informacji i tak próbowała wykorzystać byłego oficera marynarki Ala Blake’a. Służby te w zasadzie kontrolowały sytuację (utworzyły listę ok. 2 tys. Japończyków przeznaczonych do zatrzymania w momencie wybuchu wojny) i były zgodne, że ze strony większości Nisei, a nawet Issei, bezpieczeństwu państwa nic nie zagraża ${ }^{55}$.

Sprawa z 1941 roku skomplikowała jednak położenie Japończyków w Stanach Zjednoczonych, zwłaszcza Issei. Głównymi postaciami tej afery szpiegowskiej, oprócz attaché morskiego pracującego w Los Angeles Itaru Tachibany, byli bowiem Issei Toraichi Kono (były szofer i sekretarz Charliego Chaplina) i dr Takahashi Furosawa. Zaangażowanie w szpiegostwo na rzecz Japonii mogło podważyć i tak już niezbyt pozytywny wizerunek społeczności japońskiej w USA. Zdając sobie z tego sprawę zarówno Issei, jak i Nisei składali deklaracje lojalności wobec Stanów Zjednoczonych. Na wiosnę JACL rozpropagowała deklarację „Japanese American Creed” autorstwa Mike'a Masaoki. Wyrażała ona dumę z bycia Amerykaninem, uznanie dla możliwości, jakie stwarza państwo i całkowitą lojalność wobec niego oraz gotowość obrony przed każdym wrogiem $^{56}$. Przewodniczący Central Japanese Association, Kichitaro Muto podczas specjalnej audycji radiowej stwierdził: „stowarzyszenie przygotowuje się do uruchomienia programu, dzięki któremu bardziej efektywnie wykorzysta swój sprzęt i personel do współpracy z lokalnymi i federalną władzą w celu stłumienia szpiegostwa wśród japońskiej ludności” ${ }^{57}$. Welfare Commitee of the Central Japanese Association wydał także publikację noszącą nazwę The American's Creed będącą w rzeczywistości plagiatem „Japanese American Creed” ${ }^{58}$. Również Committee for Democratic Treatment for Japanese Residents in Eastern States, organizacja założona w 1940 roku w Nowym Jorku przez amerykańskich obywateli pochodzenia japońskiego, zadeklarowała lojalność i całkowite poparcie dla działań

55 F. MacDonnell, Insidious Foes: The Axis Fifth Column and the American Home Front, Guilford 2004, s. 82-84; P. Loureiro, Japanese Espionage and American Countermeasures in Pre-Pearl Harbor California, "The Journal of American-East Asian Relations" 1941, t. 3, nr 3, Special Issue - December 7: The Pearl Harbor Attack (Fall 1994), s. 197-210, JSTOR, [dostęp 08.03.2015]; B. Kumamoto, op. cit., s. 45-75. Na temat sprawy z 1941 roku: Y. Ichioka, National Security on the Eve of Pearl Harbor: The 1941 Tachibana Espionage Case and Implicated Issei Leaders, [w:] Before Internment..., s. 204-226; zob. także: P. Loureiro, The Imperial Japanese Navy and Espionage: The Itaru Tachibana Case, „The International Journal of Intelligence and Counterintelligence" 1989, t. 3, nr 1, s. 105-121.

56 Tekst deklaracji w: B. Hosokawa, JACL..., s. 278-279.

57 Y. Ichioka, National Security..., s. 217.

58 Ibidem, s. 217-218. 
władz państwowych. Uczyniła to w liście do sekretarza wojny Henry’ego Stimsona i wydając oświadczenie ${ }^{59}$.

Deklaracje lojalności i współpracy wywarły raczej niewielki wpływ na politykę władz państwowych wobec społeczności japońskiej. Dyskusja na temat charakteru tej polityki toczyła się od dawna. Kwestia ta, przynajmniej w odniesieniu do Hawajów, była obecna w planach wojskowych już od lat dwudziestych, gdy Wydział Planowania Wojennego opracował „Projekt Obrony Oahu”, zakładający w przypadku ataku japońskiego m.in. wprowadzenie prawa wojennego i internowanie Japończyków uznanych za stanowiących zagrożenie. Taka linia postępowania utrzymała się w kolejnych planach wojennych, zakładających, w najlepszym wypadku, nielojalność mniejszości japońskiej wobec państwa amerykańskiego. Zgadzał się z nią także Prezydent Franklin D. Roosevelt, który uznał za przydatne w sytuacji problemowej umieszczenie tych Japończyków, którzy posiadali ożywione kontakty z krajem Cesarza (poprzez japońskie statki przybywające na Hawaje), w obozach koncentracyjnych ${ }^{60}$.

O nielojalności Nikkei przekonany był także Departament Stanu. W tajnym dokumencie z 1934 roku uznano, że w momencie wybuchu wojny „,cała ludność japońska na Zachodnim Wybrzeżu powstanie i przeprowadzi sabotaż. Będzie wszelkimi sposobami dążyć do zneutralizowania Zachodniego Wybrzeża i uczynienia go bezbronnym" ${ }^{6}$. Nieufność wzmogła się do 1941 roku. Przed atakiem na Pearl Harbor Departament Wojny opracował plan, zakładający zakaz wkraczania lub pozostawania przez alien enemies na terenie Kanału Panamskiego, Puerto Rico i Alaski, deportowanie wszystkich osób tej kategorii do kontynentalnej części państwa oraz zakaz wkraczania i opuszczania przez nich Terytorium Hawajów (poza lokalnymi wyjątkami) i ograniczający swobodę ich poruszania się po nim ${ }^{62}$. Mała grupa badaczy uznała, że wpływ na decyzje podejmowane przez Prezydenta czy sekretarza wojny i ich plany dotyczące Nikkei w ostatnim roku pokoju i po wybuchu wojny, miały przechwycone i rozszyfrowane wiadomości przesyłane między Tokio a placówkami dyplomatycznymi USA. Zdecydowana większość historyków odrzuca jednak taką możliwośćç3.

59 Committee for Democratic Treatment for Japanese Residents in Eastern States to Henry L. Stimson, 13 sierpnia 1941, Japanese American Veterans Association,javadc.org, online archive, doc id: 8203; odpowiedź na list i treść oświadczenia - doc id: 8228, [dostęp 15.03.2015].

60 G. Robinson, By Order of the President: FDR and the Internment of Japanese Americans, Cambridge-London 2001, s. 54-57. F. D. Roosevelt nie miał oczywiście na myśli obozów koncentracyjnych $w$ znaczeniu jakie nadali in naziści podczas II wojny światowej. Termin ten przed wojna miał inne znaczenie i był szeroko używany.

61 Cyt. za: B. Kumamoto, op. cit., s. 49.

${ }^{62}$ Henry L. Stimson to Attorney General, 7 marca 1941, www.michiweglyn.com/years-of-infamy -2/michis-research, [dostęp 20.10.2014].

${ }^{63}$ Za taką tezą opowiedzieli się M. Lowman, w książce MAGIC: The Untold Story of U. S. Intelligence and the Evacuation of Japanese Residents from the West Coast during WWII (Provo 2000) 
Na kilka miesięcy przed wybuchem wojny kwestia lojalności Japończyków zamieszkałych w Stanach Zjednoczonych została nagłośniona za sprawą Martina Diesa. Był on demokratą, kongresmenem z Teksasu i przewodniczącym House on Un-American Activities Commitee. W lecie 1941 roku, kierowany przez niego komitet rozpoczął przesłuchania w sprawie japońskiego szpiegostwa i sabotażu na Zachodnim Wybrzeżu. Szybko zaowocowały one doniesieniami publikowanymi w prasie, które stawiały Japończyków w niekorzystnym świetle ${ }^{64}$. O tym, jak bardzo nerwowa była atmosfera wokół postawy Nikkei w obliczu wojny, może świadczyć prywatny list kongresmena Johna D. Dingella, wysłany w sierpniu do Prezydenta Roosevelta. Dingell napisał w nim, że państwo powinno przygotować się do umieszczenia 10 tys. Japończyków z Hawajów w obozach koncentracyjnych, co więcej, pozostali Japończycy, czyli 150 tys., mieli stanowić rezerwę przeznaczoną do odwetów (reprisal reserve) ${ }^{65}$.

Zaostrzenie sytuacji międzynarodowej i otrzymywanie sprzecznych informacji skłoniło Roosevelta do uzyskania dokładniejszych informacji na temat potencjalnego zachowania Nikkei w przypadku wybuchu wojny. Zadanie to powierzono biznesmenowi z Detroit, Curtisowi B. Munsonowi. Raport Munsona, przedstawiony Rooseveltowi 7 listopada 1941, był owocem spotkań i rozmów z wieloma przedstawicielami wywiadu, świata biznesu, JACL czy zwykłymi mieszkańcami i dotarcia do wielu miejsc na Zachodnim Wybrzeżu. Znajdująca się w nim ocena kwestii japońskiej różniła się diametralnie od poglądów przedstawicieli sił zbrojnych. Znalazły się w nim stwierdzenia: „Nie ma japońskiego problemu na wybrzeżu. Nie będzie zbrojnego powstania Japończyków. Niewątpliwie będzie miał miejsce jakiś sabotaż finansowany przez Japonię i przeprowadzany głównie przez importowanych agentów”. Jednocześnie Munson oceniał, że szpiegostwo może być skuteczne tylko w zakresie ruchów statków, wojsk i dostaw. Co ważne, uznał, że „miejscowi Japończycy w większości są lojalni wobec Stanów Zjednoczonych, lub, w najgorszym wypadku, mają nadzieję, że zachowując spokój, mogą uniknąć obozów koncentracyjnych lub nieodpowiedzialnego tłumu" 6 .

i M. Malkin w In Defense of Internment: The Case for 'Racial Profiling' in World War II and the War on Terror (Washington 2004). Na temat sporów o roli przechwyconej korespondencji zob. B. Niiya, Magic cables, http://encyclopedia.densho.org/Magic_cables//

64 Zob. U.S. Congress, House Committee on Un-American Activities, Investigations of UnAmerican Activities in the United States, Hearings before a Special Committee on Un-American Activities on H.R.282, Appendix 6: Report on Japanese Activities, $77^{\text {th }}$ Cong., $1^{\text {st }}$ sess., Washington 1942, s. 1726-1732, archive.org [dostęp 12.03.2014].

65 G. Robinson, op. cit., s. 65. Podobny plan w 1937 roku miał opracować gen. George Patton pełniący wówczas służbę na Hawajach jako oficer wywiadu. Zakładał on, w przypadku wybuchu wojny, wzięcie jako zakładników 128 przywódców miejscowej społeczności japońskiej, co miałoby zapobiec przeprowadzeniu aktów sabotażu; M. Malkin, op. cit., s. 17.

66 Memorandum on C.B. Munson's Report „Japanese on the West Coast”, 7 listopada 1941, 
Raporty Munsona przyniosły pewien, choć minimalny, pozytywny efekt. Zwróciły uwagę, że tylko niewielka część Japończyków stanowiła zagrożenie dla bezpieczeństwa państwa. $\mathrm{W}$ rezultacie, równocześnie z opracowywaniem planów kontroli i aresztowań, tworzono program koordynowany przez Williama Donovana, mający na celu propagandowe wsparcie tych Japończyków uznanych za lojalnych ${ }^{67}$. Pewne zainteresowanie sprawą położenia Japończyków w przypadku wybuchu wojny wykazała także Pierwsza Dama Eleonor Roosevelt ${ }^{68}$.

Społeczność japońska zdawała sobie sprawę, że wybuch wojny postawi ją w bardzo trudnej sytuacji. Wraz z upływem czasu i pogarszaniem się stosunków dyplomatycznych pomiędzy Japonią i Stanami Zjednoczonymi przechodziła ona coraz bardziej od patriotyzmu japońskiego do akcentowania lojalności wobec kraju zamieszkania. Nie tylko wyrażano gotowość do walki, ale także nie unikano służby wojskowej. W momencie ataku na Pearl Harbor w różnych formacjach zbrojnych na Hawajach służyło 1543 Nisei, z czego jedną trzecią stanowili ochotnicy ${ }^{69}$. W listopadzie kilkudziesięciu Nisei rozpoczęło naukę w Fourth Army Intelligence School w Presidio w Kalifornii, stając się pierwszymi z kilku tysięcy Nisei i Kibei, którzy podczas wojny z Japonią służyli w Military Intelligence Service jako tłumacze ${ }^{70}$. Tuż przed wybuchem wojny pewne środowiska Nikkei próbowały przekonać władze w Waszyngtonie do sprawiedliwego traktowania w przypadku jej wybuchu, na co uzyskały zapewnienie m.in. prokuratora generalnego Francisa Biddle ${ }^{71}$. Z drugiej strony można odnieść wrażenie, że wielu Japończyków w Stanach Zjednoczonych aż do końca miało nadzieję, że do konfliktu zbrojnego jednak nie dojdzie. Te nadzieje dobrze odzwierciedla postawa prasy japońskiej, zwłaszcza „Nippu jiji”, najstarszej i największej gazety japońskojęzycznej na Hawajach:

wiosną i latem 1941 r. [...] komentatorzy wciąż zaniżali prawdopodobieństwo działań wojennych i podtrzymywali nadzieję na pojednanie. W kwietniu, „Nippu jiji”, zbagatelizowało możliwość japońskiej akcji zbrojnej przeciwko Singapurowi i obszernie omawiało oświadczenie premiera Konoye, zgodnie z którym stosunki ze

www.michiweglyn.com/years-of-infamy-2/michis-research, [dostęp 18.11.2014]. Podobne stanowisko Munson zawarł już w raporcie wstępnym z końca października. Dokument zawiera słowa: „The Japs here, especially the citizen is straining every nerve to show their loyalty to U.S. The Japs here are in more danger from us than we from them". Memorandum, John F. Carter to Franklin D. Roosevelt, 22 października 1941, President's Secretary Files (PSF) Subject Files, John F. Carter, March-October 1941, Franklin D. Roosevelt Library and Museum Website, [dostęp 18.02.2015].

67 Memorandum, John F. Carter to Franklin D. Roosevelt, 18 listopada 1941, PSF Subject Files, John F. Carter, November-December 1941, FDR Library and Museum Website, [dostęp 18.02.2015].

68 Zob. G. Robinson, op. cit., s. 71.

69 R. A. Wilson, W. K. Hosokawa, op. cit., s. 153.

70 Zob. J. C. McNaughton, Nisei Linguists: Japanese Americans in the Military Intelligence Service during World War II, Washington D.C.: Department of the Army 2006.

71 E. Azuma, op. cit., s. 185. 
Stanami Zjednoczonymi się nie pogorszą. Pod koniec lipca, po tym jak Roosevelt zamroził japońskie aktywa w Stanach Zjednoczonych w odwecie za okupację przez Armię Imperialną południowych Indochin, „Nippu jiji” podkreślało, że zamrożenie nie będzie miało wpływu na hawajskich doho, którzy będą mogli kontynuować wysyłanie pieniędzy do Japonii. We wrześniu, październiku i listopadzie, uwaga była skupiona na dyplomatycznych negocjacjach w Waszyngtonie, które wydawały się podtrzymać nadzieję na kompromis. Pełna nadziei do samego końca „Nippu jiji”, 6 grudnia zamieściła nagłówek: „Kryzys Dalekowschodni nieco osłabł, nie będzie wojny na Pacyfiku"'72.

Lata 1930-1941 były dla Nikkei jednymi z najtrudniejszych. Oprócz nierozstrzygniętych problemów dotyczących akceptacji przez społeczeństwo amerykańskie, pojawiły się kolejne związane z agresywną polityką zagraniczną Japonii. Społeczność japońska była podzielona, i to nie tylko na generacje. $\mathrm{W}$ ich obrębie podziały i różnice zdań także były obecne. Najbardziej problematycznym aspektem pozostaje poparcie dla japońskiej polityki zagranicznej. Jej masowe i ofiarne poparcie, w szczególności wojny z Chinami, mogło wzbudzać niepokój. Przeciętny Amerykanin słusznie postrzegał Japonię jako agresora prowadzącego politykę podboju ${ }^{73}$, mógł więc nie rozumieć dlaczego jest ona tak solidarnie wspierana i usprawiedliwiana. Należy jednak pamiętać, że nie była to solidarność całkowita. Nie każdy Issei popierał działania Japonii. $Z$ drugiej strony nie każdy Nisei był im przeciwny. Wraz z pogarszaniem się stosunków amerykańsko-japońskich udzielane wsparcie było coraz słabsze. Można więc wysunąć wniosek, że większość Nikkei popierała Japonię tylko w takim zakresie czasowym i środków, który nie prowadził do konfliktu z obowiązkami wobec Stanów Zjednoczonych. Nietrafne zrozumienie takiej postawy przez społeczeństwo czy armię, w połączeniu z tradycyjnymi uprzedzeniami wobec Japończyków, czyniło ich sytuację u progu II wojny światowej bardzo trudną. Kilka miesięcy po jej rozpoczęciu 110 tys. Japończyków i Amerykanów japońskiego pochodzenia, głównie z Zachodniego Wybrzeża, zostało umieszczonych w obozach internowania. Przeważająca cześć spędziła w nich większość wojny.

\section{Japanese society in the United States (1930-1941). An outline of the problem}

The Japanese started coming to the United States at the end of the XIX century. The fact that they were not welcome was reflected in the US state and

\footnotetext{
72 J. J. Stephen, op. cit., s. 39.

73 H. Cantril, Public Opinion 1935-1946, Princeton 1951, s. 1081, archive.org [dostęp 07.10. 2013].
} 
federal legislation. In the 1920s the Japanese society - embracing two generations - counted fewer than 300,000 people. The first generation, the Issei, were deprived of the right to naturalization. Their children, the Nisei - born in the United States and in the majority of cases Americanized - constituted the second generation. The Japanese lived mainly in Hawaii, as the biggest national minority, and in the West Coast, especially California. In the 1930s life was difficult for the Japanese living in the United States. Apart from the previous problems, they had to cope with new ones - connected with the economic crisis and Japan's foreign policy. Their widespread and selfless support for Japan's aggression against China was not only disapproved of by Americans; it also complicated their situation on the eve of the war. On the other hand, it was the time when the Nisei actively joined political life. Their biggest organization, the Japanese American Citizen League (JACL) was quite successful and in the Territory of Hawaii some Japanese became members of the local legislature for the first time.

Key words: Japanese American, race relations in the USA, Territory of Hawaii, West Coast, JACL

\section{Bibliografia}

Źródła

Dokumenty opublikowane w Internecie

Committee for Democratic Treatment for Japanese Residents in Eastern States to Henry L. Stimson, 13 sierpnia 1941, Japanese American Veterans Association, javadc.org, online archive, doc id: 8203; odpowiedź na list i treść oświadczenia - doc id: 8228.

Henry L. Stimson to Attorney General, 7 marca 1941, www.michiweglyn.com/yearsof-infamy-2/michis-research.

Memorandum on C.B. Munson's Report „Japanese on the West Coast”, 7 listopada 1941, www.michiweglyn.com/years-of-infamy-2/michis-research.

Memorandum, John F. Carter to Franklin D. Roosevelt, 22 października 1941, President's Secretary File (PSF) Subject Files, John F. Carter, March-October 1941, Franklin D. Roosevelt Library and Museum Website.

Memorandum, John F. Carter to Franklin D. Roosevelt, 18 listopada 1941, PSF Subject Files, John F. Carter, November-December 1941, FDR Library and Museum Website.

\section{Dokumenty opublikowane drukiem}

Commission on Wartime Relocation and Internment of Civilians Personal Justice Denied: Report of the Commission on Wartime Relocation and Internment of Civilians, Seattle 1997. 
U.S. Congress, House Committee on Un-American Activities, Investigations of UnAmerican Activities in the United States, Hearings before a Special Committee on Un-American Activities on H.R.282, Appendix 6: Report on Japanese Activities, $77^{\text {th }}$ Cong., $1^{\text {st }}$ sess., Washington 1942 , archive.org.

\section{Autobiografie}

Inouye D. K. with Elliot L., Journey to Washington, Englewood Cliffs 1967.

\section{Literatura}

Azuma E., Between Two Empires: Race, History and Transnationalism in Japanese America, New York 2005.

Cantril H., Public Opinion 1935-1946, Princeton 1951, archive.org.

Daniels R., Asian America: Chinese and Japanese in the United States since 1850, Seattle 1988.

Daniels R., The Politics of Prejudice: The Anti-Japanese Movement in California and the Struggle for Japanese Exclusion, Berkeley-Los Angeles-London 1977.

Duus M. U., The Japanese Conspiracy: The Oahu Sugar Strike of 1920, Berkeley-Los Angeles 1999.

Hosokawa B., JACL: in Quest of Justice. The History of the Japanese American Citizens League, New York 1982.

Hosokawa B., Nisei: The Quiet Americans, New York 1969.

Ichioka Y., „Dai Nisei Mondai”: Changing Japanese Immigrant Conceptions of the Second Generation Problem, 1902-1941, [w:] Before Internment: Essays in Prewar Japanese American History, (red.) G. H. Chang, E. Azuma, Stanford 2006.

Ichioka Y., The Issei: The World of the First Generation Japanese Immigrants 1885-1924, New York 1988.

Ichioka Y., Japanese Immigrant Nationalism: The Issei and the Sino-Japanese War, 1937-1941, „California History” 1989, t. 69, nr 3, JSTOR [dostęp 8.03.2015].

Ichioka Y., National Security on the Eve of Pearl Harbor: The 1941 Tachibana Espionage Case and Implicated Issei Leaders, [w:] Before Internment: Essays in Prewar Japanese American History, (red.) G. H. Chang, E. Azuma, Stanford 2006.

Jin M., Beyond Two Homelands: Migration and Transnationalism of Japanese Americans in the Pacific, 1930-1955, praca doktorska, Santa Cruz, University of California 2013, nieopublikowana, escholarship.org.

Kent N. J., Hawaii: Islands Under the Influence, Honolulu 1993.

Kumamoto B., The Search for Spies: American Counterintelligence and the Japanese American Community 1931-1942, “Amerasia Journal” 1979, t. 6, nr 2, MetaPress. 
Loureiro P., Japanese Espionage and American Countermeasures in Pre-Pearl Harbor California, "The Journal of American-East Asian Relations" 1994, t. 3, nr 3, Special Issue - December 7, 1941: The Pearl Harbor Attack, JSTOR.

Loureiro P., The Imperial Japanese Navy and Espionage: The Itaru Tachibana Case, "The International Journal of Intelligence and Counterintelligence" 1989, t. 3, nr 1 .

Lowman M., MAGIC: The Untold Story of U. S. Intelligence and the Evacuation of Japanese Residents from the West Coast during WWII, Provo 2000.

MacDonnell F., Insidious Foes: The Axis Fifth Column and the American Home Front, New York-Oxford 1995.

Malkin M., In Defense of Internment: The Case for 'Racial Profiling' in World War II and the War on Terror, Washington 2004.

Matsumoto V., Farming a Home Place: Japanese American Community in California, 1919-1982, Ithaca 1993.

McNaughton J. C., Nisei Linguists: Japanese Americans in the Military Intelligence Service during World War II, Washington D.C.: Department of the Army 2006.

$\mathrm{Ng}$ W., Japanese American Internment during World War II, Westport-London 2002.

Nisei Voices: Japanese American Students of the 1930s - Then \& Now, (red.) J. Hirohata, P. T. Hirohata, San Jose 2004.

Nordyke E. C., Matsumoto Y. S., The Japanese in Hawaii: a historical and demographic perspective, "The Hawaiian Journal of History" 1977, t. 11, evols.library.manoa. hawaii.edu.

Ogawa D., Kodomo no tame ni - For the Sake of the Children: The Japanese American Experience in Hawaii, Honolulu 1978.

Robinson G., By Order of the President: FDR and the Internment of Japanese Americans, Cambridge-London 2001.

Salyer L. E., Baptism by Fire: Race, Military Service and U.S. Citizenship Policy, 1918-1935, "Journal of American History" 2004, t. 91, nr 3.

Stephan J. J., Hawaii Under the Rising Sun: Japan's Plans for Conquest after Pearl Harbor, Honolulu 2002.

Tamura E. H., Americanization, Acculturation and Ethnic Identity: The Nisei Generation in Hawaii, Urbana-Chicago 1994.

Wilson R. A., Hosokawa W. K., East to America: A History of the Japanese in the United States, New York 1980.

Yoo D. K., Growing up Nisei: Race, Generation, and Culture among Japanese American of California, 1924-1949, Urbana 2000.

\section{Wywiady, zbiory Densho, archive.densho.org}

Hiro Nishimura, wywiad przeprowadził T. Ikeda, 28 kwietnia 2009, Densho Visual History Collection. 
Ben Uyeno, wywiad przeprowadził D. Goto, 1 czerwca 1998, Densho Visual History Collection.

George Yoshida, wywiad przeprowadzili A. Ito, J. Pai, 18 lutego 2002, Densho Visual History Collection.

Densho Encyclopedia, encyclopedia.densho.org:

Kelli Y. Nakamura, Sanji Abe, http://encyclopedia.densho.org/Sanji_Abe//

Ch. M. Lyon, Dual citizenship, http://encyclopedia.densho.org/Dual_citizenship//

B. Niiya, Magic cables, http://encyclopedia.densho.org/Magic_cables//

B. Niiya, Tokutaro Slocum, http://encyclopedia.densho.org/Tokutaro\%20Slocum//

\section{Strony internetowe}

http://www.censusrecords.com/search?censusyear=1930\&race=japanese

S. Lu, The Nanjing Atrocities Reported in the U.S. Newspapers, 1937-38, http://www. readex.com/readex-report/nanjing-atrocities-reported-u-s-newspapers-1937-38 